\title{
Competitive Interactions between Natural Populations of Pink and Chum Salmon from Puget Sound and Coastal Washington, USA
}

\author{
Marisa N.C. Litz, Aaron M. Dufault, Andrew M. Claiborne, James P. Losee, and Tyler J. Garber
}

Washington Department of Fish and Wildlife, 1111 Washington Street SE, Olympia, Washington 98501, USA

Keywords: Pink Salmon, Chum Salmon, competition, age-at-maturity, productivity, ocean conditions

Natural populations of pink (Oncorhynchus gorbuscha) and chum salmon (O. keta) make up the highest returns of Pacific salmon to Washington, USA and many stocks spawn in the same watersheds, leading to density dependent interactions that persist across all life stages (Fig. 1). From 1967-2017, annual returns of pink salmon used in this study averaged 2,210,481 (range: 413,269 to 7,813,504) and from 1968-2017, returns of chum salmon averaged 1,010,333 (range: 174,334 to $2,662,673$; Fig. 2). In this region, pink salmon predominantly return in odd years and are associated with reduced survival of chum salmon, but also other species, including Chinook salmon (O. tshawytscha, Ruggerone and Goetz 2004) and southern resident killer whales (Orcinus orca, Ruggerone et al. 2019). For chum salmon, stocks interacting with pink salmon exhibit strong biennial patterns in abundance (Gallagher 1979) with regular even- and odd-year variations in size (Pratt 1974), age-at-maturity (Smoker 1984), and productivity (Ruggerone and Neilsen 2004). However, there has not been a comprehensive review of these biological attributes in decades. Competition between pink and chum salmon in Washington can occur during any life history stage, except in coastal populations where there are no pink salmon producing systems. Interestingly, coastal chum salmon populations also exhibit strong inter-annual variations in adult abundance and size, suggesting that competition during the overlapping marine period may be most critical for establishing the distinct even- and odd-year patterns.

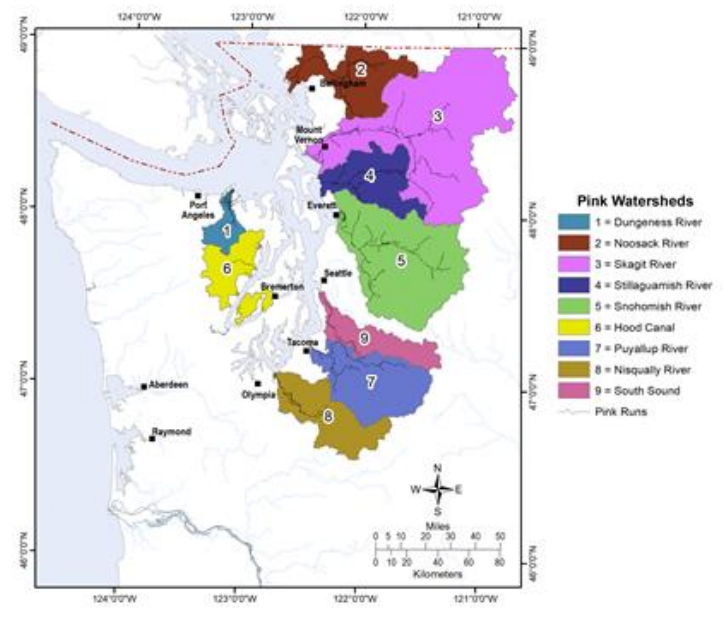

Fig. 1. Location of and pink salmon (top) and chum salmon (bottom) watersheds in Puget Sound and coastal Washington, USA (Map: D. Gombert, WDFW).

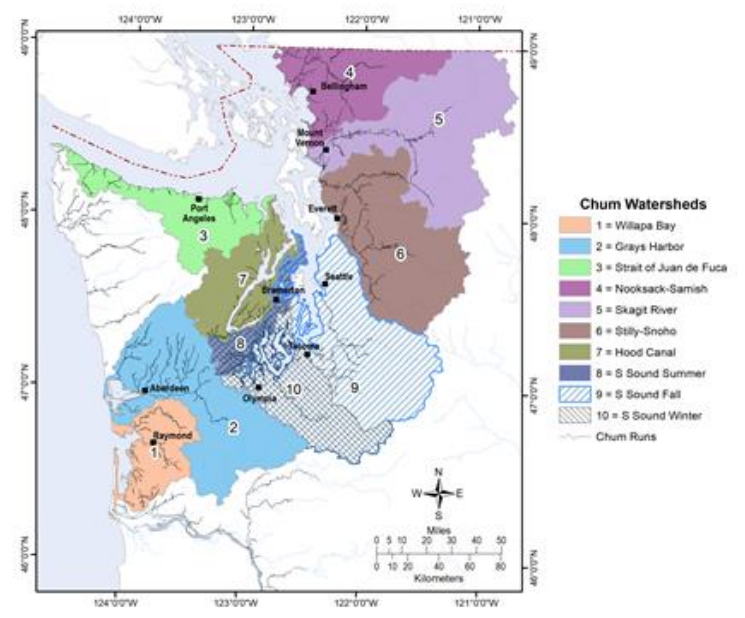




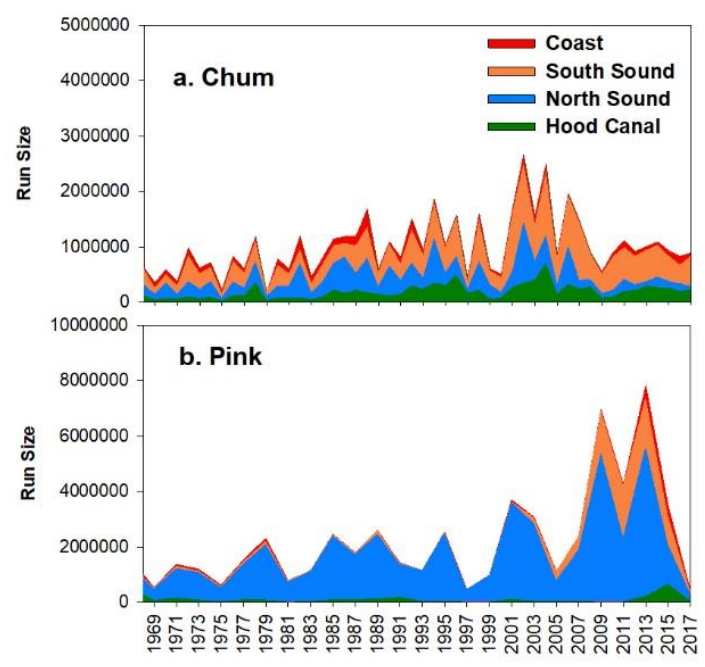

Fig. 2. Reconstructed run sizes of a) chum salmon and b) pink salmon returning to Puget Sound and coastal Washington, USA (1967-2017).

In this study, we investigated the effects of competition between natural populations of Puget Sound and coastal Washington pink and chum salmon over five decades using a weight of evidence approach to determine where and when competition occurs. Specifically, we tested for even- and odd-year differences in chum salmon abundance and adult weight by return year, and fry production, fry size, and adult age-at-maturity by brood year using Student's $t$-tests. We used natural log-transformation for fry and adult abundances, fry size (FL, mm) and adult weight $(\mathrm{kg})$. For age composition proportions, we used a logit transformation. In addition, we used Ricker residuals (standardized to a mean of 0 and standard deviation of 1) from spawner and recruit relationships to evaluate temporal trends in productivity from ten populations of each species to determine whether there were regular inter-annual differences in chum salmon productivity by brood year.

We were also interested in the effect of environmental variation on pink and chum salmon productivity. To analyze this, we first quantified spatial covariation across regions by calculating Pearson correlation coefficients for each stock within a species (Malick and Cox 2016). Next, we ordinated productivity across populations using two complementary approaches: principal component analysis (PCA) and nonmetric multidimensional scaling (NMS). By using both methods, the goal was to reduce the number of variables in the time series and detect patterns in temporal variation. Lastly, we regressed PC or NMS axes scores on environmental variables to determine which parameter best explained variation in productivity across populations. We selected basin-scale environmental variables based on previous analyses (Stachura et al. 2014) and aligned them with scores of the PC and NMS axes for the period of fry outmigration (brood year +1 ), which is recognized as a period of high but variable mortality. The environmental variables were aggregated by winter (October-March) or summer (April-September) and included the Multivariate El Niño-Southern Oscillation Index (MEI, Kobayashi et al. 2015), the North Pacific Gyre Oscillation Index (NPGO, DiLorenzo et al. 2008), and the Pacific Decadal Oscillation Index (PDO, Mantua et al. 1997).

Our analysis focused on four regions: Washington Coast (Willapa Bay, Grays Harbor, and the Strait of Juan de Fuca; all fall run timing), South Puget Sound (aggregated populations with summer, fall, and winter run timing), North Puget Sound (Nooksack, Samish, Stillaguamish, Snohomish, and Skagit River systems; all fall run timing), and Hood Canal (fall run timing only). Overall, chum salmon run sizes were $25 \%$ lower in pink (odd) run years for coastal populations, $23 \%$ lower in South Sound, 55\% lower in North Sound, and 24\% lower in Hood Canal. South Sound chum salmon summer and fall runs and North Sound Stillaguamish-Snohomish and Skagit chum salmon fall runs had abundances that were significantly (Student's $t$-test $p<0.05$ ) lower in odd years (Fig. 3). The Skagit system supported the largest pink salmon population, accounting for $40 \%$ of the total returns of Washington pink salmon over the study period. Therefore, it is not surprising that Skagit chum salmon populations displayed the greatest inter-annual variation in biological attributes at every life history stage. 

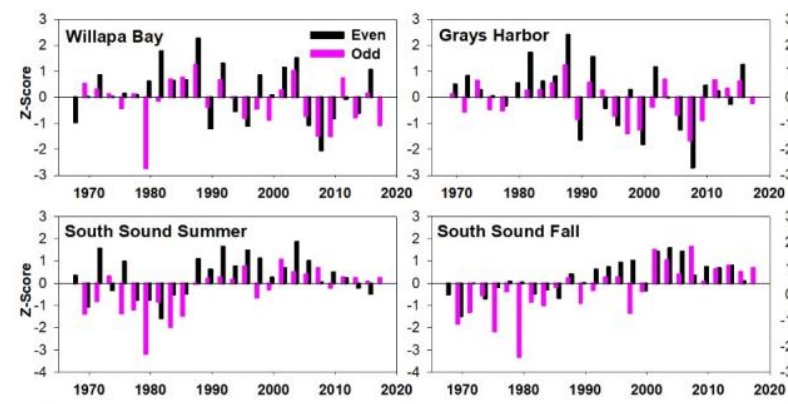

$\begin{array}{llllllllllll}1970 & 1980 & 1990 & 2000 & 2010 & 2020 & 1970 & 1980 & 1990 & 2000 & 2010 & 2020\end{array}$
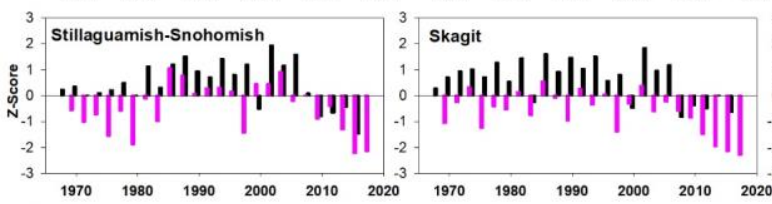

Hood Cana

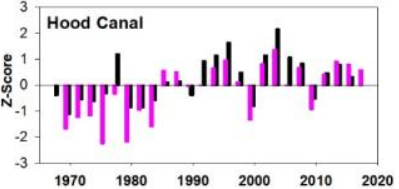

We compiled chum salmon fry abundance estimates from screw trap catches in pink-producing rivers in the Strait of Juan de Fuca (Dungeness, 2005-2017), South Sound (Nisqually, 2008-2017), North Sound (Skagit, 19962017), and Hood Canal (Duckabush, 2010-2017). Overall, we determined that $62 \%$ fewer chum fry emigrated from freshwater with juvenile pink salmon in even years compared to odd years when there were no juvenile pink salmon (Fig. 4). The difference was significant for the Dungeness $(p=0.02)$ and Skagit $(p<0.01)$ Rivers (fall run timing), but not for the Nisqually (winter run timing) or Duckabush (fall run timing). However, fry lengths (average \pm SD) determined from Dungeness catch $(n=14,738)$ did not significantly vary between even $(39.3 \pm 4.2 \mathrm{~mm})$ and odd years $(39.8 \pm 5.2 \mathrm{~mm})$, suggesting that chum and pink salmon fry were not directly competing for resources during the outmigration period.

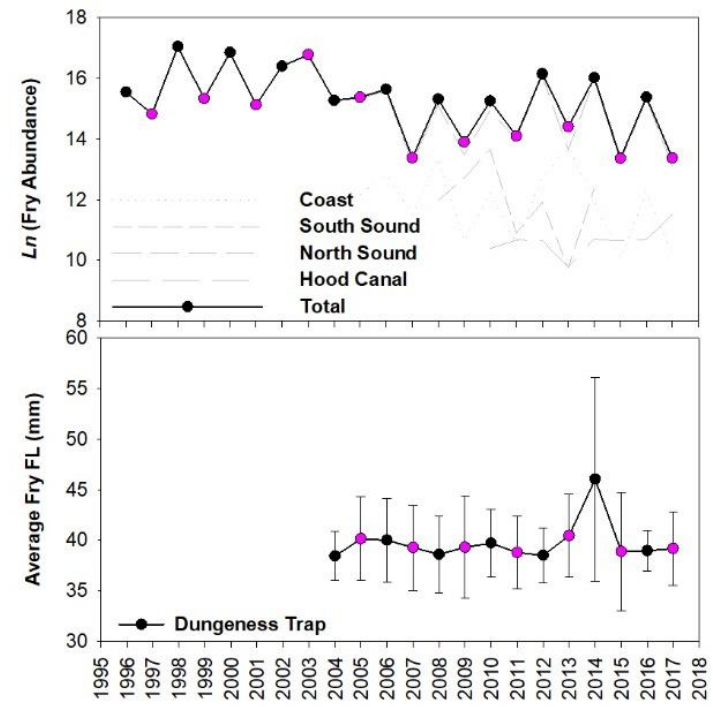

Fig. 4. Fry abundances summed across region (top) and average ( \pm SD) fry lengths (bottom) sampled from the Dungeness River population in the Strait of Juan de Fuca, Washington USA by brood year $($ black $=$ even brood year and pink = odd brood year).

Using age data processed from thousands of chum salmon scales sampled each year on spawning grounds or in commercial and recreational fisheries throughout Washington, we found biennial differences in age-at-maturity (Fig. 5). Odd brood years (outmigration with pink salmon) produced $15 \%$ more 3-year-olds than 4-year-olds, while even brood years (outmigration without pink salmon) produced 17\% more 4-year-olds than 3-year-olds, and these 
differences were highly significant $(p<0.01)$. The net result was higher overall adult chum salmon abundances returning to Washington in even (non-pink salmon) years than odd years. This suggests that competition pressure on the high seas during the second ocean winter may be determining age-at-maturity and that chum salmon might be interacting with pink salmon originating from areas outside of Puget Sound during this period. Moreover, commercially harvested chum salmon weighed $0.15 \mathrm{~kg}$ less in odd years when abundances were lower, although this difference was not significant. However, we did note that average chum salmon weight from commercial landings decreased by $0.02 \mathrm{~kg} \mathrm{yr}^{-1}$, meaning that on average, chum salmon in 2017 weighed $0.96 \mathrm{~kg}$ less than they did in 1970.

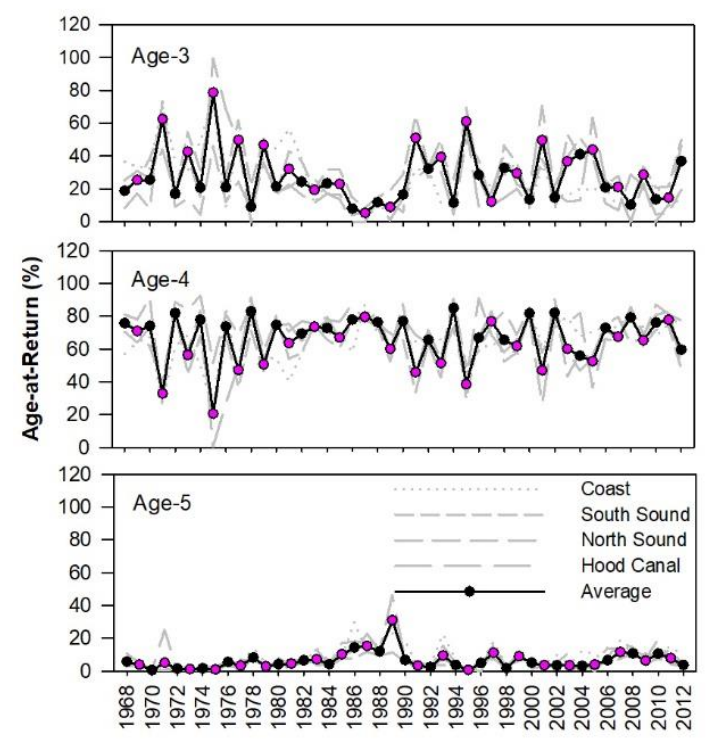

Fig. 5. Average age-at-return (\%) for age-3 (top), age-4 (middle), and age- 5 (bottom) chum salmon spawners by brood year (black $=$ even brood year and pink = odd brood year) determined from scale ages across regions of Puget Sound and coastal Washington, USA.

For pink salmon, we did not find any trends in productivity, but there was evidence of regional covariance at fine spatial scales (Fig. 6), with populations fluctuating between exceptionally high (> 7 million in 2013) and low (< 500,000 in 2017) abundances in recent years, concurrent with dramatic shifts in ocean conditions. When ordinated in multivariate space, we found that the first PC and NMS axes were inversely related $(r=-0.98)$, capturing $44.7 \%$ and $57.6 \%$ of the variation in the pink salmon dataset, respectively. When regressed against summertime NPGO values, both axes scores were significantly $\left(r^{2}=0.49\right.$ for PC and $r^{2}=0.41$ for NMS, both $\left.p<0.01\right)$ correlated with that index (Fig. 7). These results suggest that climate patterns captured by the phase of the NPGO, such as sea surface height (associated with variation in salinity, nutrients, and chlorophyll- $a$ ) may be important drivers for survival of pink salmon during the outmigration period. The second axes explained $17.7 \%$ (PC) and 22.9\% (NMS) of the variation in pink salmon productivity, but neither were associated with any environmental variables.
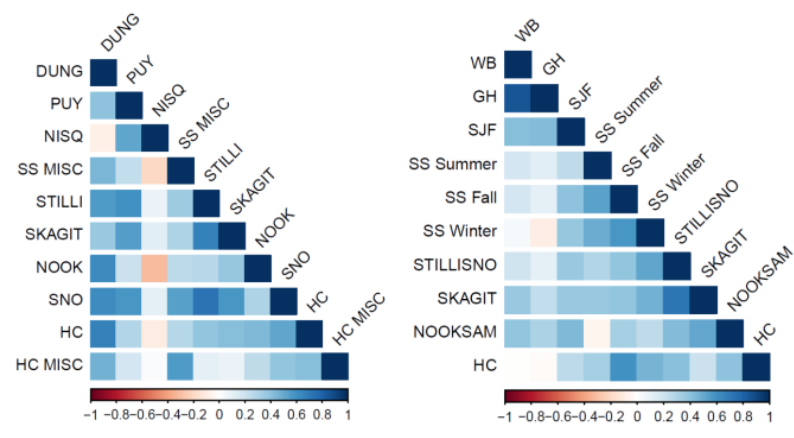

Fig. 6. Pearson correlation coefficients $(r)$ for comparisons between standardized Ricker residuals in populations of pink salmon (left) from the Coast: DUNG = Dungeness; South Sound (SS): PUY = Puyallup, NISQ = Nisqually, and SS MISC; North Sound: Skagit, NOOK = Nooksack, SNO = Snohomish; and Hood Canal: HC and HC MISC. Values are also shown for chum salmon (right) from the Coast: $\mathrm{WB}=$ Willapa Bay, GH = Grays Harbor, and SJF = Strait of Juan de Fuca (all fall run timing); South Sound (SS): summer, fall, and winter run timing; North Sound: STILLISNO = StillaguamishSnohomish, Skagit, and NOOKSAM = Nooksack-Samish (all fall run timing); and Hood Canal (HC, fall run timing only). 

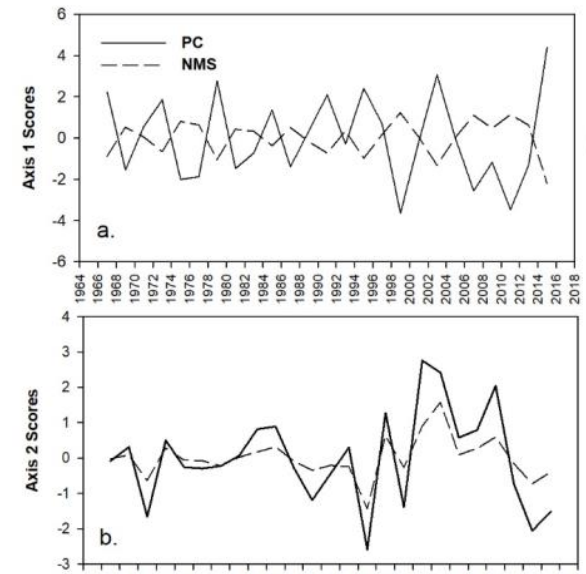

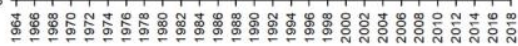
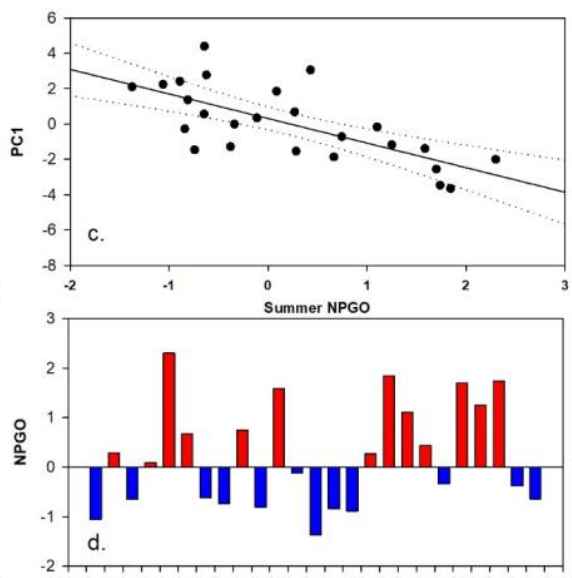

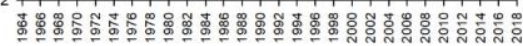

Fig. 7. Scores for a) axis 1 and $b$ ) axis 2 pink salmon productivity ordinated using Principal Component Analysis (PCA) and nonmetric multidimensional scaling (NMS); c) the association between PC1 scores and summer (April-September) North Pacific Gyre Oscillation Index (NPGO) values; and d) summer NPGO values.

Chum salmon also displayed regional covariance in productivity, but only three fall populations had significantly lower values in odd brood years (Willapa Bay and Grays Harbor on the Coast and Skagit in North Sound). Similar to previous findings (Malick and Cox 2016), we did note that productivity trended downwards in some chum salmon populations (the summer and winter runs in South Sound and fall Stillaguamish-Snohomish run in North Sound), especially after 1996 (Fig. 8). However, fall chum in Hood Canal trended upwards over the entire time series. Unlike pink salmon, when we ordinated chum salmon productivity residuals in multivariate space, neither the resulting PC nor NMS axes were correlated with any environmental variables, meaning that variation in chum salmon productivity could not explained by the basin-scale indices.
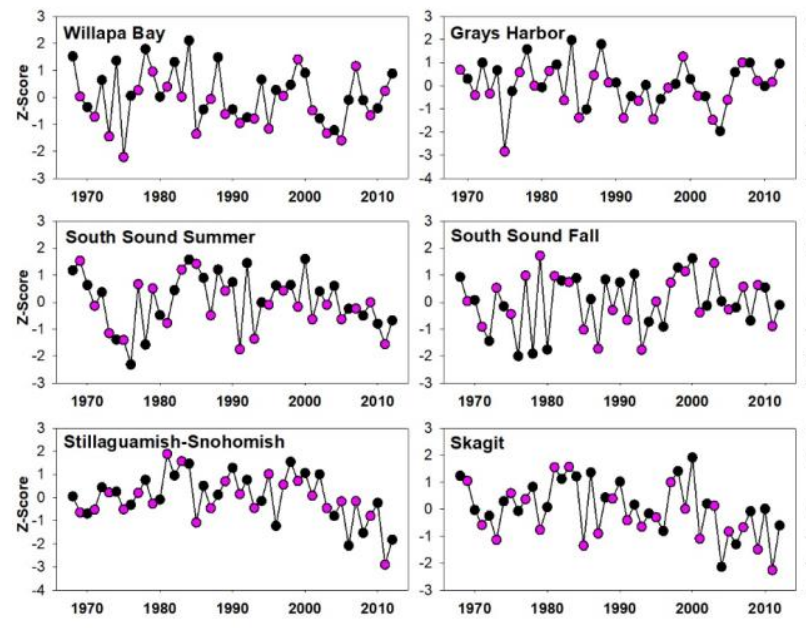
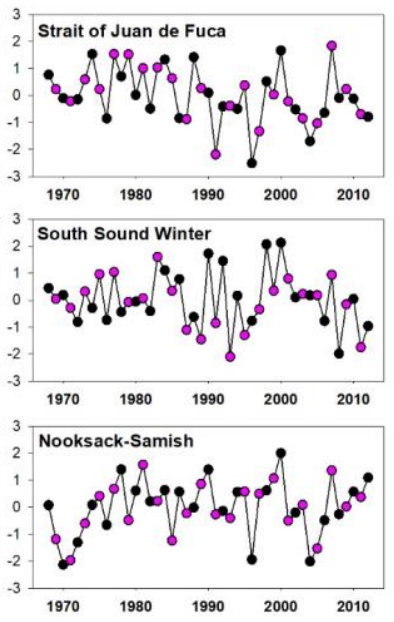

Fig. 8. Standardized Ricker residuals for chum salmon populations by brood year (black $=$ even year and pink $=$ odd year) from the Coast: Willapa Bay, Grays Harbor, and Strait of Juan de Fuca (fall run timing); South Sound: Summer, Fall, and Winter run timing; North Sound: Stillaguamish-Snohomish, Skagit, and Nooksack-Samish (fall run timing); and Hood Canal (fall run timing only).

Overall, we found compelling evidence of biennial differences in chum salmon attributes at all life history stages, including populations where there are no pink salmon, suggesting that both direct and indirect competition with pink salmon occurs. The magnitude of the effect seems to vary with pink salmon abundance. Across all of Washington, but especially in the Skagit River of North Puget Sound where populations of pink salmon are the most abundant, numbers of adult chum salmon spawners and outmigrating fry were lower in years overlapping with pink salmon. Chum salmon productivity was also lower in odd brood years, indicating that pink salmon affect recruitment. Inter-annual differences in abundance were related to variation in age-at-maturity, with odd brood 
years producing more 3-year-olds and even brood years producing more 4-year-olds. This result implies that competitive interactions affecting growth rates during the second ocean year are critical for determining when chum salmon return to spawn. However, pink salmon productivity was also sensitive to basin-scale environmental variation, suggesting that while competition can drive productivity patterns in natural populations, other factors such as environmental variability may be equally important for survival.

\section{REFERENCES}

Di Lorenzo, E., N. Schneider, K.M. Cobb, P.J.S. Franks, K. Chhak, A.J. Miller, J.C. McWilliams, S.J. Bograd, H. Arango, E. Curchitser, T.M. Powell, and P. Rivière. 2008. North Pacific Gyre Oscillation links ocean climate and ecosystem change. Geophys. Res. Lett. 35.

Gallagher, A.F., Jr. 1979. An analysis of factors affecting brood year returns in the wild stocks of Puget Sound chum (Oncorhynchus keta) and pink (Oncorhynchus gorbuscha). M.Sc. thesis, Univ. Washington, Seattle. $152 \mathrm{pp}$.

Kobayashi, S., Y. Ota, Y. Harada, A. Ebita, M. Moriya, H. Onoda, K. Onogi, H. Kamahori, C. Kobayashi, H. Endo, K. Miyaoka, and K. Takahashi. 2015. The JRA-55 Reanalysis: general specifications and basic characteristics. J. Meteor. Soc. Jpn. 93: 5-48.

Malick, M.J., and S.P. Cox. 2016. Regional declines in productivity of Pink and Chum Salmon stocks in Western North America. PLoS ONE. 11(1): e0146009.

Mantua, N.J., S.R. Hare, Y. Zhang, J.M. Wallace, and R.C. Francis. 1997. A Pacific Decadal Oscillation with impacts on salmon production. Bull. Am. Meteorol. Soc. 78: 1069-1079.

Pratt, D.C. 1974. Age, sex, length, weight, and scarring of adult chum salmon (Oncorhynchus keta) harvested by Puget Sound commercial net fisheries from 1954 to 1970: supplemental progress report, Marine Fisheries Investigation, Puget Sound Commercial Net Fisheries. Washington Department of Fisheries, Olympia. 78 pp.

Ruggerone, G.T., and F.A. Goetz. 2004. Survival of Puget Sound chinook salmon (Oncorhynchus tshawytscha) in response to climate-induced competition with pink salmon (Oncorhynchus gorbuscha). Can. J. Fish. Aquat. Sci. 61: 1756-1770.

Ruggerone, G.T., and J.T. Neilsen. 2004. Evidence for competitive dominance of Pink salmon (Oncorhynchus gorbuscha) over other Salmonids in the North Pacific Ocean. Rev. Fish Biol. Fish. 14: 371-390.

Ruggerone, G.T., A.M. Springer, L.D. Shaul, and G.B. van Vliet. 2019. Unprecedented biennial pattern of birth and mortality in an endangered apex predator, the southern resident killer whale, in the eastern North Pacific Ocean. Mar. Ecol. Progr. Ser. 608: 291-296.

Smoker, W.W. 1984. Genetic effect on the dynamics of a model of pink (Oncorhynchus gorbuscha) and chum salmon (O. keta). Can. J. Fish. Aquat. Sci. 41: 1446-1453.

Stachura, M.M., N.J. Mantua, and M.D. Scheurell. 2014. Oceanographic influences on patterns in North Pacific salmon abundance. Can. J. Fish. Aquat. Sci. 71: 226-235. 